\title{
The Design of Portable Battery Charging Devices Using Motorcycle Wheel Round
}

\author{
Feranita \\ Department of Electrical Engineering, \\ Faculty of Engineering, Universitas \\ Riau, Indonesia \\ Ery Safrianti* \\ Department of Electrical Engineering, \\ Faculty of Engineering, Universitas \\ Riau, Indonesia
}

\author{
Firdaus \\ Department of Electrical Engineering, \\ Faculty of Engineering, Universitas \\ Riau, Indonesia
}

Ade Hidayat

Department of Electrical Engineering,

Faculty of Engineering, Universitas

Riau, Indonesia

*corresponding author: Ery Safrianti,esafrianti@eng.unri.ac.id

\begin{abstract}
The design of the utilization of motorcycle wheel rotation for portable battery charging aims to make a device that can be used to charge batteries or gadgets by utilizing motorcycle wheel rotation. This tool works by using the rotation of a motorcycle's wheels into electric power for charging power bank or cell phone needs. This tool consists of 3 parts, namely dynamo, a rectifier circuit, and a regulator circuit. From testing the tools that have been made, it is proven that the device can work and produce an output voltage of $5 \mathrm{~V}$ and a maximum current of $0.95 \mathrm{~A}$. The power produced is 4.75 Watt. This tool can charge a cell phone for $\mathbf{0 - 1 0 0 \%}$ in 226 Minutes and charge a power bank for $50 \%$ for 131 Minutes. The recommended speed of the motorbike when charging is $30 \mathrm{Km} / \mathrm{h}$.
\end{abstract}

Keywords-Chargers, Dynamos, Regulators, motorcycle rotation

\section{INTRODUCTION}

The limited source of electrical energy that comes from the grid of PLN makes it difficult for mobile users to carry out activities that require an electrical energy source to charge cell phone batteries. If the charge on the cell phone battery is used up, the cell phone cannot be used. Today, mobile phones are one of the primary needs of humans. One form of alternative energy that can be utilized comes from bicycle pedaling motion energy (Putri et al., 2014). A cell phone charger utilizing bicycle pedal energy has already been made before by the leading mobile phone company Nokia TM. In June 2010, Nokia introduced a product called the Nokia Bicycle Charger Kit DC 14. The Nokia Bicycle Charger Kit is specifically for Nokia mobile phones. The workings of the Nokia Bicycle Charger Kit dynamo power output will produce AC current, then flowed to the electronic charger unit to charge the handphone battery. The Nokia charger unit breaks the flow when the bike reaches a speed of $45-50 \mathrm{~km} / \mathrm{hour}$. Research related to alternative energy for charging mobile phone batteries has also been conducted by Benni Frandinata Maizir (Maizir, 2012) by utilizing back energy. This mechanical mobile phone battery charging device utilizes back energy as an energy source. Back energy moves magnets and coils, thus producing a voltage that can be used to charge cell phone batteries (Goesbike, 2011). But the utilization system has not been maximized because it uses bicycle pedaling as an initial means of movement in this system.

A battery charging device is a device used to charge energy into batteries by conducting an electric current. This tool is widely used by electronic devices, one of which is mobile phones. This tool converts AC voltage to DC voltage according to the voltage required by the battery. The amount of voltage is regulated by an electronic circuit. Then this tool can also stabilize the voltage in accordance with the needs of mobile phones. In 2016 the number of motorcycle users was around 105,150,082 (Indonesian Central Statistics Agency). This is the background of this research, which is making a tool that can be used to charge batteries or gadgets by utilizing motorcycle wheel rotation. It is hoped that the use of this alternative energy can be more efficient and saves time in charging batteries, without having to wait and stay in a public place just to charge the gadget.

\section{MethodOLOGY}

The block diagram of the design can be seen in Figure 1 below. Basically, this tool works to convert mechanical energy into electrical energy using the working principle of dynamos. The electricity produced by the dynamo is then rectified with a diode rectifier and the regulator flows into. The regulator functions as a voltage limiter and also a voltage stabilizer and then flowed to the current amplifier using a DC to DC converter, the output of the circuit functions as a 5 VDC battery charging. 


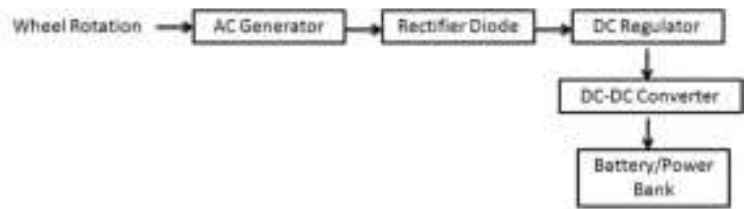

Figure 1: Block diagram of the device design

\section{A. Device design}

In realizing the series of devices to be made, designing and assembling according to plan, the work specifications of the series to be developed are making engineering tools for utilizing the rotation of the motorcycle wheels for charging portable batteries, which consist of mechanical design of laying the dynamo on the front wheels of the motorcycle, circuit regulator and current amplifier design, circuit design (DC to DC converter) and overall circuit design.

\section{B. Mechanical Design of Dinamo Placement on Motorcycle Front Wheel}

Dynamo placement as shown in Figure 2. The picture 2 is the position of the construction of the dynamo. Lo needs to be considered in the position of the laying construction between the dynamo and the wheel must be aligned so that when there is movement or vibration in the suspension wheel, the dynamo remains at the position connected to the wheel. It also needs to be considered a safe position from dust and dirt on the road so that the dynamo remains durable.

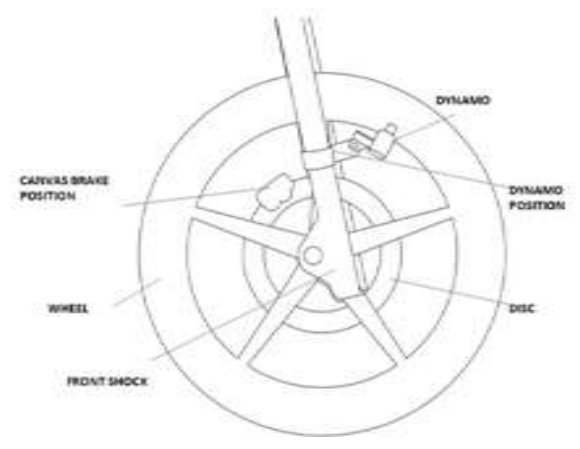

Figure 2: Dynamo placement

\section{Design of Regulatory Circuits and Current Amplifiers}

Circuit regulator and current amplifier as shown in the following figure 3 .

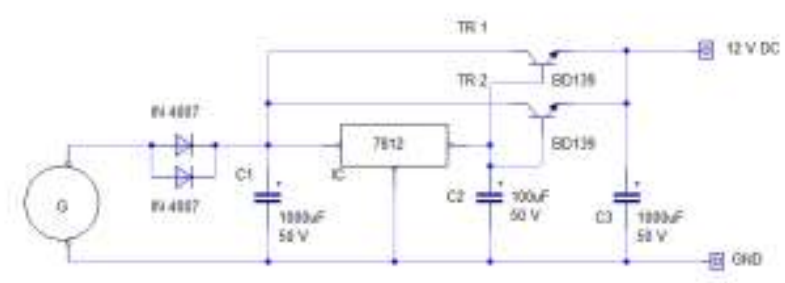

Figure 3: Regulatory Circuits and Current Amplifiers
Figure 3 is a series of regulators with a current amplifier that serves to limit the output voltage of the dynamo and strengthen the regulator output current, this circuit uses a diode IN4007 which functions as a voltage rectifier and then as a back voltage from the regulator to the generator, 1000uf / $50 \mathrm{~V}$ capacitor mounted on the diode output functions as a filter, so that it becomes a pure DC voltage, IC 7812 is used as a voltage stabilizer regulator with a maximum output voltage of $12 \mathrm{VDC}$, the output voltage of IC 7812 is given a $100 \mathrm{uF} /$ $50 \mathrm{~V}$ capacitor as a voltage filter, for current amplifiers using as many BD139 transistors 2 pieces are installed in parallel, the base pin gets a voltage from output 7812, the collector pin is connected directly to the output di4007, emitter pin Transistor BD139 as output voltage 12 VDC, the energy issued by the current amplifier Transistor BD139 is the same as the voltage fed to the base pint the resistor.

\section{Circuit Design (DC to DC Converter)}

The current amplifier circuit is shown in Figure 4. It is using IC AD 84064 as DC-DC Converter, this circuit functions to change the $12 \mathrm{VDC}$ voltage coming from the regulator circuit to $5 \mathrm{VDC}$ then inductor $200 \mathrm{uH}$ to amplify the current coming from the output pin 2 IC AD84064, the LED functions as an indicator pin 8 is used as voltage feedback from a USB connection to a power bank or battery to determine the voltage level of the charged battery.

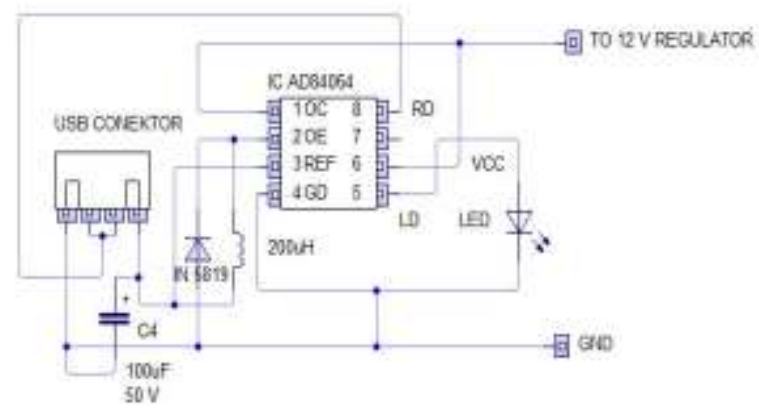

Figure 4: Current Amplifier Circuit (DC To DC Converter)

\section{E. Overall Circuit Schema}

This design illustrates some of the circuits described above connected to a whole series forming a system that functions to utilize the rotation of a motorcycle wheel to rotate the dynamo (generator) to produce a voltage which is then rectified by a rectifier diode and filtered by a $1000 \mathrm{uF} / 50 \mathrm{~V}$ capacitor so that the voltage becomes pure DC, then the DC voltage is connected to the regulator DC circuit which serves to stabilize the output voltage, the voltage coming from the generator is unstable because it follows the speed or slow rotation of the motorcycle wheel which is paired to the dynamo (generator) the faster the rotation of the dynamo, the voltage will increase so conversely the slower the dynamo turns the voltage will go down, IC 7812 in the regulator circuit serves to stabilize the fixed voltage at 12 VDC despite a change in the output voltage. Then the regulator output circuit is connected to the base pin of the BD139 transistor as a current amplifier, and the output voltage on the Emitter pin (E) on the BD139 transistor is connected to the DC-DC Converter circuit, this circuit functions as a voltage or current controller in the Charger. The 
output of this circuit is a USB connector that will be connected to the load in the form of a Smartphone or Power bank using a USB cable, following the overall circuit image that has been designed.

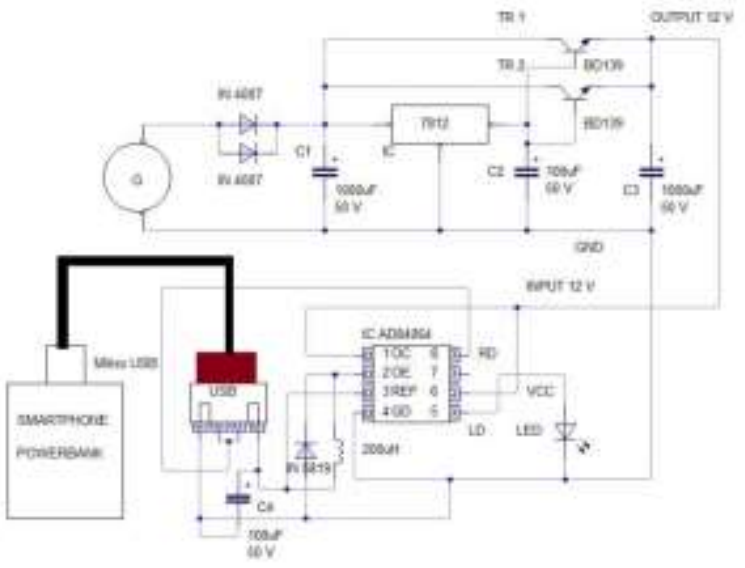

Figure 5: Schematic of the Overall Circuit Device

How to operate the device?

To avoid errors in operating the tool and maintain the durability of the tool, the authors make the steps on how to operate the tool as follows.

a) Connect the dynamo rotor (DC generator) to the rotating motorbike wheels.

b) Connect the USB cable to the Smartphone or power bank Battery.

c) Check the maximum speed of the motorcycle when the dynamo (DC Generator) is connected.

d) The maximum speed of the motorcycle when charging is $70 \mathrm{~km} / \mathrm{h}$.

Hardware Specifications:

Hardware specifications needed at the time of implementation are motorcycle dynamo, IC 7812, 1000uF / 50 $\mathrm{V}$ capacitors, $100 \mathrm{uF} / 50 \mathrm{~V}$ capacitors, $200 \mathrm{uH}$ Inductors, AD84064 ICs, battery type (18650).

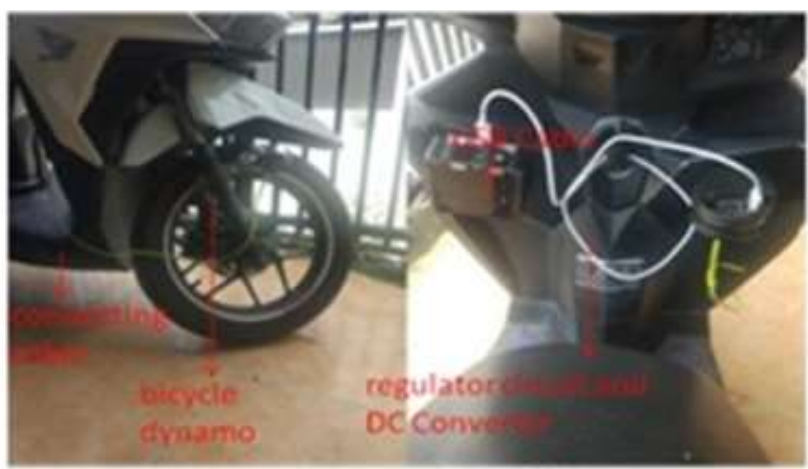

Figure 6: Installation of a circuit on a motorcycle

\section{F. Hardware Set}

This circuit is a whole series of devices made, there are five interconnected blocks making it a battery or smartphone charger, the blocks are Rectifier (diode), the regulator circuit uses (IC 7812) with $1000 \mathrm{uF} / 50 \mathrm{~V}$ capacitor, current amplifier circuit (Transistor BD139) NPN, DC to DC converter, and output circuits use 100uF / $16 \mathrm{~V}$ capacitors, along with pictures of all the devices that have been made.

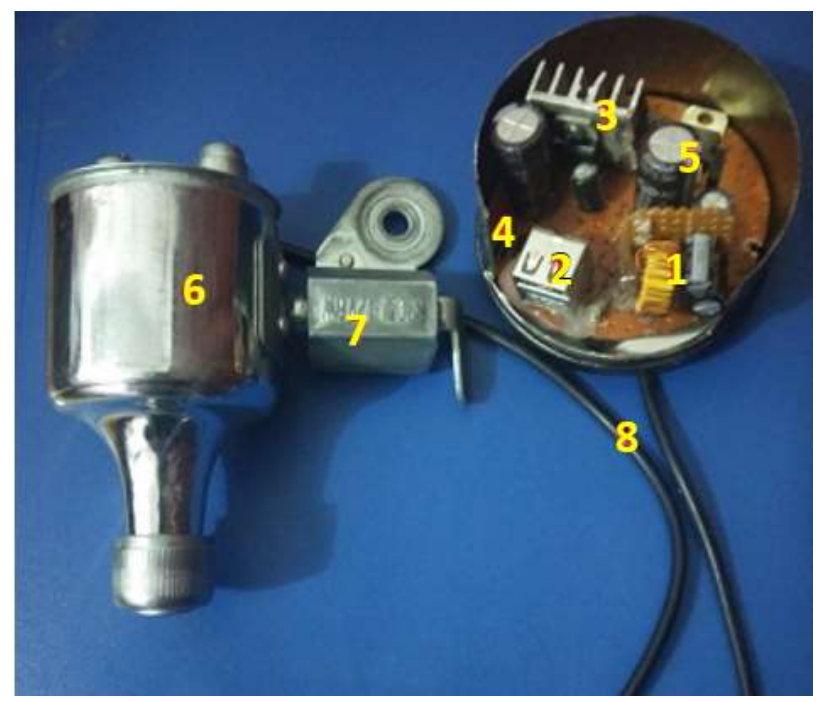

Figure 7: The overall image of the tool

The picture above is a whole series of tools that have been made, where the series is divided into 7 series blocks, following a table of information from the numbering that has been made.

Table 1: Description of Circuit Blocks

\begin{tabular}{|c|c|c|c|}
\hline No & $\begin{array}{l}\text { Circuit } \\
\text { Name }\end{array}$ & Component & Function \\
\hline 1 & $\begin{array}{c}D C-D C \\
\text { Converter }\end{array}$ & $\begin{array}{l}\text { Inductor } 200 \mathrm{uH} \\
\text { Capacitor } \\
220 / \mathrm{uF} \\
\text { IC AD84064 }\end{array}$ & $\begin{array}{c}\text { As a circuit to produce a } 5 \\
\text { Volt voltage and as an } \\
\text { output charger. }\end{array}$ \\
\hline 2 & $\begin{array}{l}\text { USB } \\
\text { Connector } \\
\text { Output. }\end{array}$ & USB Connector & $\begin{array}{c}\text { As a link between the } \\
\text { charger circuit with a } \\
\text { smartphone using a USB } \\
\text { cable. }\end{array}$ \\
\hline 3 & Regulator & $\begin{array}{l}\text { IC } 7812 \\
\text { Cap } \\
1000 u F / 50 \mathrm{~V}\end{array}$ & $\begin{array}{c}\text { As a } 12 \text { Volt voltage } \\
\text { stabilizer circuit from the } \\
\text { dynamo input. }\end{array}$ \\
\hline 4 & $\begin{array}{l}\text { Voltage } \\
\text { Rectifier }\end{array}$ & $\begin{array}{l}\text { Diode IN } \\
4007\end{array}$ & $\begin{array}{l}\text { As a voltage rectifier } \\
\text { circuit derived from the } \\
\text { input. }\end{array}$ \\
\hline 5 & $\begin{array}{c}\text { Current } \\
\text { Amplifier }\end{array}$ & $\begin{array}{l}\text { Transistor } \\
\text { BD139 and } \\
\text { capacitor } \\
1000 \mathrm{uF} / 50 \mathrm{~V}\end{array}$ & $\begin{array}{l}\text { As an amplifier output } \\
\text { current regulator and DC } \\
\text { voltage filter at the output } \\
\text { using a capacitor. }\end{array}$ \\
\hline
\end{tabular}




\begin{tabular}{|c|c|l|c|}
\hline 6 & $\begin{array}{c}\text { AC } \\
\text { Generator }\end{array}$ & $\begin{array}{l}\text { Bicycle } \\
\text { Dynamo 12 V }\end{array}$ & $\begin{array}{c}\text { As an energy generator and } \\
\text { transformer of the motion } \\
\text { energy of the wheel } \\
\text { rotation into electrical } \\
\text { energy. }\end{array}$ \\
\hline 7 & $\begin{array}{c}\text { Generator } \\
\text { handle }\end{array}$ & Hook iron & $\begin{array}{c}\text { To connect and place an } \\
\text { AC generator (bicycle } \\
\text { dynamo) on the front wheel } \\
\text { shock. }\end{array}$ \\
\hline
\end{tabular}

\section{RESULT AND DISCUSSION}

\section{A. Device Test Result}

At this stage, testing is done on each series to find out whether the tool is running as expected, then proceed with testing the overall tool that will be displayed in tabular and figure form, and ending with an evaluation of the test results to get the level of success of the tool that has been made, the following stages of testing have been carried out.

\section{B. Testing of Dynamo Voltage Against Motorcycle Wheel Speed.}

This test is done by measuring the dynamo output voltage before the regulator circuit and DC-DC Converter using an analog multi ester with a measurement scale of 50Vac and dynamo speeds that are different to get the minimum and maximum speed on the dynamo and determine the effect of speed with the generated voltage, following the results table testing.

Table 2: Results of Dynamo Voltage Testing with various speeds

\begin{tabular}{|c|c|c|}
\hline $\mathrm{km} / \mathrm{h}$ & $\begin{array}{c}\text { Voltage } \\
\text { (Vac) }\end{array}$ & Dynamo condition \\
\hline 21 & 13.58 & Normal \\
\hline 40 & 15.04 & Normal \\
\hline 60 & 25.65 & warm \\
\hline 70 & 23.78 & Hot \\
\hline
\end{tabular}

From the test data above, it can be made a comparison chart between the speed and the voltage generated by the dynamo, so we can see the effect of speed on that voltage, the following graph is the dynamo voltage test data on speed.

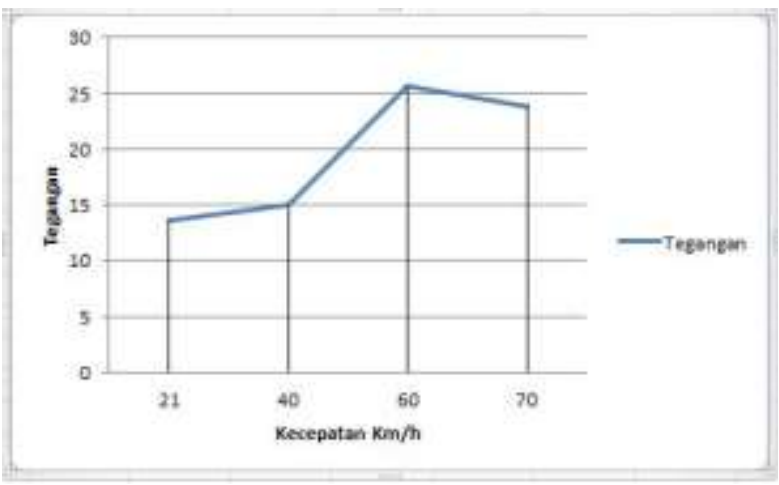

Figure 8: Graph of the effect of velocity on voltage.

\section{Testing the Output Voltage of Regulator Circuits.}

This test is done by measuring the output voltage on the regulator circuit that is on pin 3 (output) IC 7812 using an analog multitester with a measurement scale of 50VDC with different speed variations from the dynamo, the aim is to determine the voltage value at the regulator output, the following table shows the voltage test results regulator output.

Table 3: Results of Voltage Regulator Testing

\begin{tabular}{|c|c|c|}
\hline $\begin{array}{c}\text { Speed } \\
\mathrm{Km} / \mathrm{h}\end{array}$ & $\begin{array}{c}\text { Voltage } \\
\text { dynamo }\end{array}$ & $\begin{array}{c}\text { Voltage } \\
\text { Regulator }\end{array}$ \\
\hline 21 & $13.58 \mathrm{Vac}$ & 12.05 \\
\hline 30 & $15.04 \mathrm{Vac}$ & 12.05 \\
\hline 50 & $25.65 \mathrm{Vac}$ & 12.34 \\
\hline 70 & $23.78 \mathrm{Vac}$ & 12.30 \\
\hline
\end{tabular}

\section{DC To DC Converter Output Circuit Voltage Test.}

This test is done by measuring the output voltage on the DC to DC Converter using the Charger Doctor measuring instrument, which aims to determine the value of the voltage generated by this circuit, along with pictures of the results of tests that have been carried out.

Table 4: Test Results for DC-DC Converter Output Voltage.

\begin{tabular}{|c|c|c|c|}
\hline $\mathrm{km} / \mathrm{h}$ & Dynamo & Regulator & $\begin{array}{c}D C-D C \\
\text { Converter }\end{array}$ \\
\hline 21 & 13.58 & 12.05 & 5.06 \\
\hline 30 & 15.04 & 12.05 & 5.06 \\
\hline 50 & 25.65 & 12.05 & 5.06 \\
\hline 70 & 23.78 & 12.05 & 5.06 \\
\hline
\end{tabular}

\section{E. Testing of Output Circuit Current Against Motor Wheel Speed}

This test is done by measuring the output current from the circuit to the USB connector using a seven-segment display module that is installed in series with a positive voltage to the charger load, the load used is a Power bank battery, aiming to determine the output current of the circuit, following the test results that have been performed.

Table 5: Test Results for Circuit Output Current

\begin{tabular}{|c|c|c|}
\hline $\mathrm{km} / \mathrm{h}$ & $\begin{array}{c}\text { Voltage } \\
\text { Output (V) }\end{array}$ & $\begin{array}{c}\text { Current } \\
\text { Output(A) }\end{array}$ \\
\hline 21 & 5 & 0.6 \\
\hline 30 & 5 & 0.8 \\
\hline 50 & 5 & 0.85 \\
\hline 70 & 5 & 0.95 \\
\hline
\end{tabular}

\section{F. Smartphones Charging Tests At $30 \mathrm{Km} / \mathrm{h}$}

This test is done by connecting the smartphone with a charger circuit that is made, in this test the smartphone users is the Samsung brand with a battery capacity of $9.88 \mathrm{Wh} / 3.8$ $\mathrm{V}$, the charger circuit is made to produce a voltage of $5 \mathrm{~V} / 1$ A, the purpose of This test is to ensure that the tool can work 
to recharge the smartphone battery, the results of the tests that have been carried out can be seen in Table 6 .

Table 6: Battery Charging Test Results

\begin{tabular}{|c|c|c|c|}
\hline Time & $\begin{array}{c}D C- \\
D C\end{array}$ & Current(A) & $\begin{array}{c}\% \text { Battery } \\
\text { HP }\end{array}$ \\
\hline 46 Menit & $5 \mathrm{~V}$ & 0.80 & $0-25$ \\
\hline 50 Menit & $5 \mathrm{~V}$ & 0.76 & $25-50$ \\
\hline 58 Menit & $5 \mathrm{~V}$ & 0.75 & $50-75$ \\
\hline 72 Menit & $5 \mathrm{~V}$ & 0.71 & $75-100$ \\
\hline
\end{tabular}

From the battery charging table on the Mobile or smartphone above it can be seen that the charging time starts from $0 \%$ to $100 \%$ battery status. The total charging time is 226 minutes until the battery is full.

\section{G. Power bank Charging Test.}

This test is carried out using a power bank with a capacity of $10000 \mathrm{mAh} 5 \mathrm{~V} / 2 \mathrm{~A}$, when testing the remaining power bank power is $50 \%$ marked with 2 indicator lights, the purpose of the test is to find out the charging time using a charger that has been designed. The test results can be seen in Table 7 .

Table 7: Results of Power bank Charging Tests

\begin{tabular}{|c|c|c|c|}
\hline Time & $\begin{array}{c}D C-D C \\
\text { Out }\end{array}$ & Current(A) & $\begin{array}{c}\text { Status Power bank } \\
\text { status (bar) }\end{array}$ \\
\hline $18: 10$ & $5 \mathrm{~V}$ & $0.80 \mathrm{~A}$ & $\begin{array}{c}2 \mathrm{bar} \\
(50 \%)\end{array}$ \\
WIB & & & $\begin{array}{c}4 \mathrm{bar} \\
(100 \%)\end{array}$ \\
\hline $20: 21$ & $5 \mathrm{~V}$ & $0.74 \mathrm{~A}$ & \\
WIB & & & \multicolumn{2}{|c}{} \\
\hline
\end{tabular}

The table above shows the results of the charging test on the power bank starting at 18:10 WIB with the status of the battery power bank showing an indicator of 2 bars or equal to $50 \%$, with a charger output voltage of $5 \mathrm{~V}$ DC with a current of $0.80 \mathrm{~A}$, it takes time for 131 minutes or the same with 2 Hours 11 Minutes, so the battery is $100 \%$ full at 20:21 WIB.

\section{CONCLUSSION}

From the results of the design and testing of the tools that have been done, it can be concluded:

1. The output voltage and current of this charger is $5 \mathrm{~V}$ with a current of $0.95 \mathrm{~A}$.

2. The device is designed to be able to charge a Mobile battery with a charging time of 226 Minutes in the condition of 0 $100 \%$.

3. The charging time for a Power bank battery under 2 Rod or $50 \%$ battery conditions is 131 Minutes or 2 Hours 11 Minutes.

4. The minimum and maximum speed of motorcycle wheels to the dynamo to be safe to use is $30-60 \mathrm{Km} / \mathrm{h}$ if more then the dynamo will be hot and easily damaged.

\section{SUGGESTION}

The devices that have been designed and tested can function well, but for the sake of further improvement of the tool the authors suggest:

a) We recommend using a dynamo that can withstand the maximum speed of the motor wheel.

b) Added protection circuit to the device to avoid damage due to short circuits.

c) The addition of an automatic tool to release and connect the motorcycle armature dynamo when it exceeds normal speed.

\section{REFERENCES}

[1] Ali, Iwan Agustiawan, Dwi Aji, "Pemanfaatan Putaran Roda Sepeda Guna Menghasilkan Energi Listrik", Prosiding Seminar Nasional XVII Rekayasa dan Aplikasi Teknik Mesin di Industri Kampus ITENAS - Bandung, 2018.

[2] Putri, A.,D., Wahyuni \& Tianur, "Pemanfaatan Energi Kayuhan Sepeda untuk pengisian baterai Hand phone", Jurnal Teknik Elektro dan Komputer, 2014.

[3] Purnomo, A, "Pemanfaatan Sepeda Statis Dengan Generator Linier untuk Pembangkit Listrik Ramah Lingkungan", Skripsi Universitas Muhammadiyah Surakarta, 2016.

[4] Maizir, Benni Frandinata, "Charger Handphone Mekanik Dengan Memanfaatkan Energi Punggung", Riau, 2012. 